\title{
Jerzy Woźnicki
}

\section{Postulat selektywnego charakteru deregulacji w szkolnictwie wyższym ${ }^{1}$}

\begin{abstract}
STRESZCZENIE. Artykuł poświęcony jest zagadnieniom deregulacji w zakresie spraw obejmowanych przez ustawę Prawo o szkolnictwie wyższym z 2005 r. Po kolejnych nowelizacjach tej ustawy w latach 2011, 2014 i 2016 sformułowany został niebudzący wątpliwości w debacie publicznej postulat deregulacji systemu. Trzeba zadać sobie jednak pytanie, czy należy określić jej granice, a jeśli tak, to jakiej są one natury i na podstawie jakich przesłanek powinny zostać zidentyfikowane. Stanowisko autora wyraża konieczność określenia takich granic. W tekście zagadnienia te zostały poddane analizie z uwzględnieniem zakresu i charakteru pożądanych ograniczeń. Wskazane też zostały obszary, które powinny być objęte regulacjami ustawowymi. Oznacza to, że deregulacja powinna mieć charakter selektywny, pozostawiając określone kwestie poza zakresem tego działania. W artykule po wprowadzeniu w problematykę przedstawiono argumentację na rzecz niezbędności zachowania szkolnictwa wyższego jako działu regulowanego. Następnie przywołano postulat deregulacji i jej uwarunkowania, z rozróżnieniem pojęć deregulacji gramatycznej, funkcjonalnej i wykonawczej, wprowadzonych przez autora. W tym kontekście sformułowano postulat nadania deregulacji charakteru selektywnego. W ślad za odnotowaniem znaczenia konstytucyjnej zasady autonomii uczelni zaprezentowano postulowane relacje $\mathrm{w}$ odniesieniu do kompetencji regulacyjnych w układzie: ustawa statut uczelni. W podsumowaniu zwrócono uwagę, że wnioskowana deregulacja z ograniczeniami wpisuje się w pożądane uwarunkowania rozwojowe instrumentarium prawnego w obszarze governance w szkolnictwie wyższym. W Dodatku przywołano fragmenty dokumentów podkreślających znaczenie dobrych praktyk w sferze stanowienia prawa dotyczącego szkolnictwa wyższego i nauki.
\end{abstract}

SŁOWA KLUCZOWE: szkolnictwo wyższe, selektywna deregulacja, autonomia uczelni, ustawa, statut

${ }^{1} \mathrm{~W}$ artykule wykorzystano wybrane tezy i stwierdzenia autora, przedstawione w jego wcześniejszych publikacjach albo opracowaniach zbiorczych FRP: Strategia rozwoju... 2009; Woźnicki 2007; Program rozwoju... 2015. 


\section{Wstęp}

Rozpoczynając proces zmian legislacyjnych w szkolnictwie wyższym, trzeba zmierzyć się z podstawowym dylematem zawartym w odpowiedzi na pytania, co i w jakim zakresie powinno być przedmiotem regulacji ustawowych, zwłaszcza tych o charakterze fundamentalnym, określających model instytucjonalny uczelni i jej relacje z interesariuszami wewnętrznymi i zewnętrznymi, oraz jaka, a w szczególności jak głęboka, powinna być ingerencja ustawowa.

Nie ma wątpliwości, że nowe przepisy powinny być przygotowywane i redagowane z odwołaniem się do intencji i rozwiązań chroniących prawo przed patologią nadregulacji. W procesie legislacyjnym trzeba nieustannie przeprowadzać symulowaną kontrolę na wyjściu, a więc uwzględniając ewentualne skutki proponowanych regulacji, tak by nie ulegać w pracach legislacyjnych nie zawsze właściwej tezie o bezwzględnym prymacie zwięzłości i niewielkiej objętości tekstu ustawy. Należy też zachowywać niezbędny krytycyzm wobec pierwotnie zakładanych lub wstępnie deklarowanych haseł $\mathrm{i}$ intencji deregulacyjnych, które mogą stanowić zagrożenia dla zasad wspólnoty i wolności uczelni. Zbyt daleko idąca deregulacja mogłaby oznaczać chaos i konflikty na uczelniach, których rozwiązaniem mogą stać się tendencje do nadregulacji statutowych. Należy także unikać nieustannego mnożenia wprowadzanych zmian w opracowywanym projekcie ustawy, istotnie wykraczających poza przyjęte założenia, co można określić jako pokusę „wszystkoizmu zmiany”.

Założenie o potrzebie nadania selektywnego charakteru deregulacji zostało zaproponowane w tekście „Strategii rozwoju szkolnictwa wyższego na lata 2010-2020 - projekt środowiskowy", opracowanej przez Fundację Rektorów Polskich dla Konsorcjum KRASP(KRePSZ)-FRP-KRZaSP i przyjętej przez jego członków przy poparciu RGNISW.

Deregulacja powinna mieć zatem charakter selektywny, a nie absolutny. Przykładowo, należy regulować wymogi jakości dzieła i przejrzystości uczelni oraz obszary gwarancji praw, w tym reguły uzyskiwania i weryfikacji efektów, działając zgodnie z ustawowymi zasadami nadzoru. Deregulacji powinny podlegać sposoby i ścieżki uzyskiwania rezultatów oraz procedury, a także szeroko rozumiany obszar mikrozarządzania w uczelniach.

Narzucanie prewencyjnej roli ustawy jako priorytetu w procesie legislacyjnym byłoby niewłaściwe. Nie należy tworzyć prawa na bazie reguł odpowiedzialności zbiorowej. Przeciwnie, należy odwoływać się do zasady zaufania i pomocniczości w procesie eliminowania źródeł patologii, wyposażając właściwe organy nadzorcze w kompetencje niezbędne do efektywnego reagowania na zdarzenia niepożądane.

$\mathrm{W}$ procesie stanowienia prawa w szkolnictwie wyższym należy odwoływać się do konstytucyjnej zasady autonomii uczelni, wskazując w założeniach do ustawy obszary niezbędnych regulacji i pożądane kierunki deregulacji. Taki proces z lat 
2015-2017 mamy już za sobą. Jego skutkiem było przyjęcie tezy o potrzebie wprowadzania w szkolnictwie wyższym zmian głębokich i dotyczących szerokiego zakresu zagadnień. Nie oznacza to jednak pozbawiania państwa jego niezbywalnych ról. Nie ma przeszkód, aby pozostawało to w zgodności z konstytucyjną zasadą autonomii uczelni, której zakres pozostaje przedmiotem regulacji ustawy zwykłej. Autonomia szkół wyższych jest fundamentalną zasadą warunkującą kreatywność kadry naukowej i gwarantującą możliwie nieskrępowane warunki rozwojowe uczelni i środowiska akademickiego. Jest oczywiste, że wymaga to ustawowego powiązania z zasadą odpowiedzialności szkoły wyższej, w ramach jej powinności działania na rzecz interesu publicznego. Wymaganie to wynika z zasady służebności uczelni, w szczególności z jej tzw. trzeciej misji.

Oznacza to bezwzględny wymóg gwarancji prawnych dla rozstrzygania spraw wewnętrznych uczelni przez jej własne organy. Powinien on jednak zostać zharmonizowany z wymogami zapewniającymi możliwości sprawowania skutecznego nadzoru przez właściwe organy państwa i ich efektywnych reakcji w przypadku zaistnienia nawet incydentalnych przypadków o charakterze patologicznym.

$\mathrm{W}$ procesie stanowienia prawa należy ograniczyć tendencję do obejmowania wszystkich podmiotów rygorystycznymi przepisami (na wszelki wypadek), wprowadzającą narzędzia kontroli powszechnej w obawie przed łamaniem reguł.

Rola państwa obejmuje także konieczność obniżania ryzyka edukacyjnego, w obliczu którego staje kandydat na studia, a następnie student, oddający w sposób nieodwracalny wybranej przez siebie uczelni najlepsze lata swego życia, nie mając pełnej zdolności do oceny jakości oferty uczelni i jej późniejszej realizacji.

Organy państwa działają w systemie nauki i szkolnictwa wyższego jako inwestor dysponujący środkami publicznymi w imieniu podatników. To nakłada na te organy obowiązek czuwania nad spełnianiem przez uczelnie wymogów konstytucyjnych: legalności, gospodarności, celowości i rzetelności. Wynika to także z ustaw innych niż te dotyczące szkół wyższych, czego badaniem zajmuje się m.in. Najwyższa Izba Kontroli, zgodnie ze swoimi kompetencjami konstytucyjnymi.

Te i inne uwarunkowania, o których będzie mowa w artykule, potwierdzają jego tezę i intencję autora osłabienia ujawniających się niekiedy nadmiernych oczekiwań deregulacyjnych oraz ograniczenia ryzyka nieposkromionego zapału deregulującego u niektórych projektodawców i opiniodawców przyszłych regulacji.

\section{Niezbędność regulacji i ich rola systemowa}

Regulacje warunkują właściwe funkcjonowanie systemu oraz wpływają na stan i postępowanie organów uczelni. Głównym regulatorem działania systemu szkolnictwa wyższego i jego rozwoju są ustawy i rozporządzenia jako narzędzia prawne polityki edukacyjnej państwa. 
Zgodnie z rozporządzeniem Prezesa Rady Ministrów z dnia 20 czerwca 2002 r. w sprawie „Zasad techniki prawodawczej” (Dz.U. nr 100, poz. 908) podjęcie decyzji o przygotowaniu projektu ustawy poprzedza się szeregiem czynności:

1) wyznaczeniem i opisaniem stanu stosunków społecznych w dziedzinie wymagającej interwencji organów władzy publicznej oraz wskazaniem pożądanych kierunków ich zmiany;

2) ustaleniem potencjalnych, prawnych i innych niż prawne, środków oddziaływania umożliwiających osiągnięcie zamierzonych celów;

3) określeniem przewidywanych skutków społecznych, gospodarczych, organizacyjnych, prawnych i finansowych każdego z rozważanych rozwiązań;

4) zasięgnięciem opinii podmiotów zainteresowanych rozstrzygnięciem sprawy;

5) dokonaniem wyboru sposobu interwencji organów władzy publicznej [...].

Zgodnie z § 2 rozporządzenia „Ustawa powinna wyczerpująco regulować daną dziedzinę spraw, nie pozostawiając poza zakresem swego unormowania istotnych fragmentów tej dziedziny". Ten ostatni wymóg techniki prawodawczej może sprzyjać pojawianiu się nadregulacji.

W dokumencie programowym KRASP z 2015 r. znaczenie i rolę regulacji przedstawiono następująco:

Regulacje zawarte $\mathrm{w}$ akcie prawnym rangi ustawowej w odniesieniu do szkolnictwa wyższego spełniają ważne funkcje wpływające na wybrane obszary w systemie: określają organizację systemu (framework), charakteryzują zakres autonomii instytucjonalnej, są gwarancją praw i wolności oraz instrumentarium obniżania ryzyka (pracownicy, studenci, doktoranci) i walki z nieprawidłowościami. Regulacje są niezbędnym źródłem tytułu do uprawnień kontrolnych i nadzorczych, a także podstawą stosunków administracyjno-prawnych w szkolnictwie wyższym. Regulacje stanowią fundament działania uczelni „prawnej” w państwie prawnym i źródło delegacji statutowych. Wyznaczają reguły gospodarki i dyscypliny finansowej (zasady odpowiedzialności, przychody, koszty, kontrola zarządeza...). Stanowią źródło tożsamości i umocowania formalnego Rady Głównej Nauki i Szkolnictwa Wyższego, konferencji rektorów, Polskiej Komisji Akredytacyjnej, komisji akredytacyjnej(ych), parlamentu studentów i krajowej reprezentacji doktorantów. Regulacje się również sposobem umocowania rynku jako regulatora (Woźnicki 2015: 84-85).

Ustawodawstwo powinno zapewniać uczelniom publicznym możliwość wyboru najbardziej odpowiedniego dla każdej z nich modelu w ramach wskazanego, niezbędnego minimum regulacji. Do tego minimum musi należeć wyczerpujące określenie w ustawie organów uczelni. Powinno ono obejmować także obowiązek uzyskiwania decyzji właściwego organu władzy publicznej albo wydawania pozwolenia przez właściwy organ państwa, warunkujących utworzenie szkoły wyższej. Ustawa musi definiować podstawowe pojęcia dotyczące uczelni i prowadzenia studiów (w tzw. słowniczku). Terminologia w szkolnictwie wyższym należy bowiem 
niewątpliwie do materii ustawowej. Prowadzenie studiów powinno odbywać się po uzyskaniu akredytacji właściwego organu wskazanego w ustawie. Uczelnie muszą być instytucjami zaufania publicznego - rozpoczęcie studiów przez młodą osobę to rodzaj inwestycji osobistej studenta. Państwo dzięki swojej roli regulacyjnej i nadzorczej jest gwarantem, że dana instytucja na takie zaufanie zasługuje.

Dla uniknięcia patologii zagrażających tożsamości uczelni jej działalność w obszarze finansów i gospodarki powinna być przedmiotem odpowiednich regulacji. Jest to obszar szczególnie wrażliwy dla reputacji szkoły wyższej. Pojawienie się w nim nieprawidłowości mogłoby destrukcyjnie wpłynąć na autorytet i pozycję uczelni w przestrzeni publicznej. Odpowiednie ustawowe wymagania regulacyjne służą zatem m.in. obniżaniu ryzyka w tej sferze.

Wypełnianie przez państwo zadań dotyczących pielęgnowania systemu i utrzymywania ładu systemowego, w tym reguł finansowania budżetowego, wymaga precyzyjnych regulacji. Odpowiednie, szczegółowe regulacje niezbędne są również do sprawowania przez państwo nadzoru polegającego na skutecznym reagowaniu w trudnych sytuacjach występujących na uczelniach. Konieczne są też regulacje określające wymogi rozliczalności i transparentności. Wskazane jest jednak ograniczenie sprawozdawczości i niektórych innych obciążeń biurokratycznych.

Proces regulowania systemu szkolnictwa wyższego wymaga respektowania zasad ciągłości i przewidywalności. Ważna jest stabilność reguł, które nie powinny podlegać zbyt częstym zmianom. Istotne jest wprowadzenie zasady, zgodnie z którą podmioty odpowiedzialne za działanie systemu nie mogą w sposób dowolny powiększać zakresu niezbędnych ich zdaniem regulacji ustawowych. Kwestie te wymagają dialogu społecznego ze środowiskiem akademickim reprezentowanym przede wszystkim przez podmioty przedstawicielskie umocowane ustawowo.

Za kluczowe należy uznać dwa poziomy regulacji: ustawę i statut uczelni. Każdy z tych aktów prawnych pełni inną rolę regulacyjną. Ustawa definiuje podstawy ustrojowe instytucji szkolnictwa wyższego oraz spełnia wymagania delegacji konstytucyjnych, w tym realizuje szczególnie ważny wymóg autonomii uczelni. Natomiast rola statutu uczelni obejmuje wypełnianie delegacji ustawowych i uregulowanie w niezbędnym zakresie obszarów nieuregulowanych w ustawie. Statut określa też wiele innych szczegółowych kwestii dotyczących wewnętrznych reguł działania szkoły wyższej.

\section{Deregulacja jako fundamentalne założenie procesu stanowienia prawa}

W świetle przyjętego rozumienia deregulacji znaczenie dla procesów deregulacyjnych mają przede wszystkim prace legislacyjne. Zakres przedmiotowy pojęcia deregulacji jest jednak zróżnicowany. $Z$ jednej strony deregulację można rozumieć 
jako proces gramatyczny (wprowadźmy tu pojęcie deregulacji gramatycznej) oznaczający tworzenie krótszego aktu prawnego albo bardziej zwięzłego, z postulowanym a priori zmniejszeniem jego objętości. $Z$ drugiej strony deregulacja może być przeprowadzona z wykorzystaniem zmian w sposobie i treści regulowania systemu, z postulatem uwolnienia go od gorsetu nadregulacji w określonym zakresie. Deregulacja taka, wprowadzająca zmiany istniejących regulacji o charakterze celowościowym bez względu na objętość tekstu, powinna być rozumiana jako deregulacja funkcjonalna. Zmiana odregulowująca działanie uczelni, wprowadzona na poziomie rozporządzeń, może zostać określona jako deregulacja wykonawcza. Oznaczałoby to przede wszystkim mniej delegacji do rozporządzeń i bardziej ograniczony ich zakres.

Działaniem istotnym z uwagi na deregulację jest przyjęcie w szerszym zakresie metody autoregulacji oraz stosowanie zasady pomocniczości. Taka samoregulacja oznacza mechanizmy regulacji własnej na niższym, instytucjonalnym poziomie w systemie szkolnictwa wyższego.

Deregulacji służy stosowanie standardów prawidłowej legislacji, obejmujących m.in. ocenę skutków regulacji (OSR), przestrzeganie standardów konsultacji społecznych i zasady partycypacji w procesie stanowienia prawa. Jakości legislacji służą dobre praktyki oraz ograniczenie stosowania tzw. zasady tępego legalizmu, szczególnie w procesie interpretacji prawa. Oznacza to, że problem deregulacji należy rozpatrywać na szerszym tle uwarunkowań związanych z kulturą stanowienia prawa.

Państwo, realizując politykę publiczną w szkolnictwie wyższym, powinno być wspierane przez instytucjonalnych partnerów środowiskowych, a w tym zwłaszcza przez umocowane w ustawach niezależne i reprezentatywne organy oraz podmioty przedstawicielskie, w tym RGNiSW i konferencje rektorów KRASP(KRePSZ) i KRZaSP, a także pozarządowe organizacje pożytku publicznego, w tym think-tanki, fundacje, stowarzyszenia i federacje twórców. Takie partnerstwo sprzyja wprowadzaniu zrównoważonych rozwiązań o charakterze deregulacyjnym.

W rozważaniach nad procesem deregulacji warto również zwrócić uwagę na deregulacyjną rolę rynku jako regulatora. Niektóre kategorie rynkowe mogą mieć zastosowanie w szkolnictwie wyższym. Do działania uczelni odnoszą się w części kategorie popytu, podaży i ceny, a w bardziej ograniczonym zakresie także samo pojęcie produktu. Zastosowanie znajduje również umowa cywilnoprawna, choć nie we wszystkich rodzajach działalności, gdyż nie stosuje się tej formy do rezultatu działalności edukacyjnej (nie zawieramy ze studentem umowy o charakterze cywilnoprawnym na wyniki kształcenia). Do szkolnictwa wyższego odnoszą się też takie kategorie, jak: sprzedaż, usługa, inwestycja, produkcja, zysk, podatek, klienci, interesariusze (stakeholders), konkurencja oraz certyfikacja produktów i licencjonowanie (w praktyce powiązane z akredytacją). Jednak szkolnictwo wyższe nie może stać się zwykłym rynkiem o charakterze sektorowym ze względu na różne ograni- 
czenia, w tym te fundamentalnej natury. Uczelnia wypracowuje nadwyżkę finansową, ale jej działanie nie jest nastawione na zysk, ponieważ cele niekomercyjne są ważniejsze od wyników ekonomicznych. Dla uczelni najważniejsza jest realizacja misji i tradycyjnego posłannictwa uniwersytetu oraz zachowanie kultury instytucji akademickiej. Nie można zatem optymalizować działania uczelni ze względu na domniemane efekty ekonomiczne.

Warunkiem utworzenia publicznej szkoły wyższej jest uzyskanie pozytywnej decyzji właściwego organu państwa. Uczelnia ma możliwość prowadzenia działalności pod warunkiem spełnienia określonych wymogów ustawowych dotyczących jej ustroju i organizacji. Wymogi te warunkują funkcjonowanie szkół wyższych. Relacje uczelnia - student mają charakter administracyjno-prawny. Obowiązuje tu tzw. władztwo zakładowe i skarga do Naczelnego Sądu Administracyjnego. Finansowanie znacznej części działań szkół wyższych ma charakter dotacyjny, a nie kontraktowy. Nie można sprywatyzować uczelni publicznej, nie ma też możliwości przekształcenia jej w spółkę, a uczelnia nie podlega regulacjom Kodeksu handlowego.

Ograniczenia rynku w szkolnictwie wyższym mają charakter fundamentalny. Zakres rynkowości szkolnictwa wyższego jest zależny od przyjętych w danym kraju rozwiązań systemowych i modelowych w stosunku do działających instytucji. Szkolnictwo wyższe ma pewne cechy, które zawsze będą ograniczać jego wolnorynkowość, ale granice stosowalności rynku jako regulatora można prawnie określać na różne sposoby.

Współcześnie rynek ze wszystkimi swoimi ograniczeniami stał się jednym z regulatorów w szkolnictwie wyższym i odgrywa rolę stymulatora rozwoju instytucji akademickich. Jego oddziaływanie możliwe jest przy obecności innych regulatorów systemowych o charakterze nierynkowym. Charakter wpływu rynku zależy od wyboru modelu i zasad finansowania publicznej instytucji akademickiej. Istotny jest też rodzaj działalności prowadzonej w uczelni. Oddziaływanie rynku jest silnie uwarunkowane przez zasady i zakres odpłatności na studia oraz stopień powszechności czesnego.

W ramach systemu szkolnictwa wyższego należy rozwijać mechanizmy rynkowe, ponieważ takie działanie sprzyja wzrostowi konkurencji między uczelniami oraz kształtuje ich partnerskie współdziałanie (zasada koopetycji).

\section{Postulat selektywnego charakteru deregulacji}

Deregulacja jest elementem koncepcji stanowienia prawa, z postulatami ograniczania pożądanych obszarów regulacji oraz podejmowania działań prowadzących do oczekiwanych efektów deregulacyjnych. W szkolnictwie wyższym niezbędna jest deregulacja, ale z założenia o charakterze ograniczonym. Postulat takiej selektywnej deregulacji został przedstawiony w 2009 r. w projekcie środowiskowym 
Strategii rozwoju szkolnictwa wyższego do $2020 \mathrm{r}$. W dokumencie tym stwierdza się m.in.:

Działaniem, które należy podjąć w celu do usunięcia nadregulacji w systemie szkolnictwa wyższego jest:

- wyeliminowanie - w ramach selektywnej deregulacji w systemie szkolnictwa wyższego - przepisów narzucających udział państwa w mikrozarządzaniu w uczelniach;

- zróżnicowanie nakładanych na uczelnie rygorów ustawowych, dotyczących dysponowania środkami finansowymi w zależności od źródła ich pochodzenia, umożliwiające racjonalizację działania uczelni [Strategia rozwoju... 2009: 101].

Selektywne podejście do procesów deregulacji pozwala na wprowadzanie zmian w pewnych obszarach, przy jednoczesnym utrzymaniu treści i zakresu niezbędnych regulacji w innych. Prawidłowo rozumiana deregulacja powinna chronić przed złymi praktykami w zakresie projektowania, stanowienia i nowelizacji prawa, zarówno na poziomie ustawowym, jak i statutowym. Nie należy za wszelką cenę dążyć do rewolucyjnej deregulacji w szkolnictwie wyższym. Trzeba liczyć się z tym, że taka deregulacja oznaczałaby przeniesienie ciężaru regulacji we wszystkich aspektach działania na same uczelnie, naruszając ład systemowy i ogólne zasady stanowienia prawa w państwie. Właściwe jest też, aby ustawa tworzyła warunki do pewnej odporności samych uczelni na nadregulacyjne tendencje członków własnych organów oraz legislatorów - twórców statutów.

\section{Regulacje a autonomia instytucjonalna}

Autonomia uczelni jest wartością nie tylko konstytucyjną, ale i fundamentalną. Zgodnie z art. 70 ust. 5 Konstytucji RP „zapewnia się autonomię szkół wyższych na zasadach określonych w ustawie". Ma ona zatem charakter ustrojowy. Zakres autonomii instytucjonalnej stanowi istotny wyznacznik w różnych modelach uczelni. Potwierdza to fundamentalny charakter pojęcia autonomii na gruncie szkolnictwa wyższego.

Dokument pn. „Deklaracja Erfurcka” z 1996 r.², poświęcony tzw. uniwersytetowi odpowiedzialnemu, zawiera m.in. następujące stwierdzenie:

Uczelnia ma stanowić odpowiedzialną wspólnotę, nie zaś anarchistyczne czy nieodpowiedzialne stowarzyszenie. Na szkołach wyższych ciąży obowiązek takiego organizowania się, aby ich decyzje podejmowane były po wszechstronnej konsultacji, lecz bez zbytniej zwłoki, a uzgodnione działania wprowadzane w czyn w pełni i sumiennie, przy minimum kosztów. Jako wspólnota uczonych i studentów uczelnia ponosi zespołową odpowiedzialność za działania podjęte przez swe władze bądź w jej imieniu.

\footnotetext{
${ }^{2}$ http://www.weu.int/documents/971118en.pdf [13.07.2017].
} 
Z zasady autonomii uczelni szkół wyższych i zasady pomocniczości wynika potrzeba uregulowania systemu przez akty normatywne o mocy powszechnie obowiązującej, ale zredukowane do niezbędnego minimum. Regulacja nie może naruszyć istoty autonomii szkoły wyższej. Zasada proporcjonalności nakazuje, aby ingerencję w działanie danego samodzielnego podmiotu ograniczyć do przypadków, gdy jest to konieczne w stopniu wymaganym do osiągnięcia zamierzonego celu reprezentującego nadrzędny interes publiczny.

Pozytywnym przykładem właściwej regulacji może być art. 4 ustawy Prawo o szkolnictwie wyższym z 2005 r. (Dz.U. nr 164, poz. 1365) w brzmieniu:

1. Uczelnia jest autonomiczna we wszystkich obszarach swojego działania na zasadach określonych w ustawie.

2. Uczelnie kierują się zasadami wolności nauczania, badań naukowych i twórczości artystycznej.

3. Uczelnie, pełniąc misję odkrywania i przekazywania prawdy poprzez prowadzenie badań i kształcenie studentów, stanowią integralną część narodowego systemu edukacji i nauki.

4. Uczelnie współpracują z otoczeniem społeczno-gospodarczym, w szczególności w zakresie prowadzenia badań naukowych i prac rozwojowych na rzecz podmiotów gospodarczych, w wyodrębnionych formach działalności, w tym w drodze utworzenia spółki celowej, o której mowa w art. 86a, a także przez udział przedstawicieli pracodawców w opracowywaniu programów kształcenia i w procesie dydaktycznym.

5. Organy administracji rządowej i organy jednostek samorządu terytorialnego mogą podejmować decyzje dotyczące uczelni tylko w przypadkach przewidzianych w ustawach.

Konieczne jest wiązanie stopnia wolności regulacyjnej z zakresem odpowiedzialności własnej przyjmowanej przez organy uczelni. Służą temu regulacje określające wymogi i zasady działania i nadzoru oraz reguły kontroli zarządczej.

\section{Postulowane relacje regulacyjne: ustawa - statut}

Zgodnie z treścią kolejnych raportów opracowanych przez Komisję ds. Strategicznych Problemów Szkolnictwa Wyższego KRASP, działającą z udziałem ekspertów z RGNiSW, obszary regulacji ustawy i statutu powinny kształtować się następująco:

Ustawa powinna określać:

- system szkolnictwa wyższego, w tym zasady tworzenia i likwidacji uczelni oraz uprawnienia ministra zgodnie z zasadą, że kompetencje nadzorcze ministra nie są domniemywane, a planistyczne, w tym inicjatywne, powinny być wykonywane z uwzględnieniem warunku przewidywalności systemowej. 
Istotne jest określenie form współpracy międzynarodowej uczelni w zakresie kształcenia i badań naukowych oraz współpracy uczelni z otoczeniem społeczno-gospodarczym. Ustawa powinna zawierać reguły sprawozdawczości i systemy informacyjne;

- organy przedstawicielskie środowiska akademickiego w systemie szkolnictwa wyższego - umocowanie instytucji na szczeblu systemowym, w tym Rady Głównej Nauki i Szkolnictwa Wyższego, Konferencji Rektorów, samorządu oraz organizacji studenckich i doktoranckich;

- ustrój uczelni - jej statut, organy, organizację uczelni oraz charakter współpracy międzyuczelnianej;

- mienie i finanse uczelni - mienie uczelni, źródła finansowania i zasady gospodarki finansowej uczelni;

- sprawy studenckie i doktoranckie, organizację studiów i inne formy kształcenia - uprawnienia do prowadzenia studiów, organizacja studiów, prawa i obowiązki studentów i doktorantów, pomoc materialna, odpowiedzialność dyscyplinarna studentów i doktorantów, a także studia podyplomowe i inne formy kształcenia;

- zasady oceny jakości kształcenia i akredytację - zadania Polskiej Komisji Akredytacyjnej, komisji środowiskowych i akredytacja międzynarodowa;

- prawa i obowiązki pracowników uczelni - ustalanie stosunku pracy pracowników uczelni, wynagrodzenie i inne świadczenia, regulowanie spraw pracowniczych;

- utrzymanie porządku i bezpieczeństwa na terenie uczelni (Woźnicki 2017b).

Statut powinien określać:

- tryb wyboru oraz skład organów uczelni;

- wymagania kwalifikacyjne, jakie muszą spełniać osoby kandydujące na stanowiska rektora, prorektorów, kierownika podstawowej jednostki organizacyjnej lub do pełnienia funkcji w organach kolegialnych uczelni;

- szczegółowe kompetencje organów jednoosobowych i kolegialnych uczelni;

- tryb pracy organów kolegialnych uczelni;

- przesłanki, tryb stwierdzania wygaśnięcia mandatu organu jednoosobowego lub członka organu kolegialnego oraz tryb wyborów uzupełniających;

- rodzaje, warunki i tryb tworzenia, likwidacji i przekształcania jednostek organizacyjnych uczelni;

- organizację i funkcjonowanie systemu biblioteczno-informacyjnego uczelni, w tym zasady korzystania z niego przez osoby niebędące pracownikami, doktorantami lub studentami uczelni, a także skład, kompetencje oraz tryb powoływania rady bibliotecznej;

- zasady zatrudniania nauczycieli akademickich; 
- kryteria oraz tryb dokonywania oceny okresowej nauczycieli akademickich, z uwzględnieniem możliwości zasięgania opinii ekspertów spoza uczelni;

- zasady i tryb dokonywania oceny nauczycieli akademickich przez studentów i doktorantów oraz sposób jej wykorzystania;

- wymagania i kwalifikacje zawodowe osób zatrudnianych na stanowiskach naukowych, naukowo-dydaktycznych i dydaktycznych;

- roczny maksymalny wymiar zajęć dydaktycznych osób zatrudnianych na poszczególnych stanowiskach;

- możliwość tworzenia własnego funduszu stypendialnego i funduszu rozwoju;

- tryb ustalania regulaminu organizacyjnego uczelni;

- tryb wyboru członków komisji dyscyplinarnych oraz ich kadencje;

- treść ślubowania studentów i doktorantów;

- przepisy porządkowe dotyczące odbywania zgromadzeń na terenie uczelni;

- warunki nadawania tytułu doktora honoris causa i innych godności honorowych oraz tryb postępowania w tych sprawach (Woźnicki 2017b).

Projektowane zmiany legislacyjne w szkolnictwie wyższym powinny uwzględniać potrzebę wzrostu znaczenia regulacji uczelnianej, dokonywanej przede wszystkim w ramach statutu. Rola i ranga statutu uczelni w systemie źródeł prawa powinny zostać zwiększone. Ustawa powinna delegować do statutów uregulowanie dotyczące m.in. wewnętrznych struktur uczelni. Wśród ważnych rozstrzygnięć ustawowych musi znaleźć się zasada domniemania funkcji regulacyjnych statutu w sprawach nieuregulowanych na poziomie ustawowym. Należy ograniczyć zakres nadmiernego stosowania trzystopniowego systemu tworzenia prawa (ustawa - rozporządzenie - statut uczelni) na rzecz dwustopniowego (ustawa - statut uczelni). Skala i zakres delegacji do aktów wykonawczych powinny zostać zmniejszone. Tym samym nastąpiłaby zmiana charakteru ministerstwa jako właściwego organu. Ministerstwo pełniłoby funkcje bardziej strategiczne - dotyczące kształtowania warunków rozwoju systemu i uczelni.

Stosowaną zasadą powinno być to, że procesy tworzenia projektu nowej ustawy oraz wprowadzanie nowych rozwiązań w systemie szkolnictwa wyższego powinny zostać poprzedzone pogłębioną diagnozą identyfikującą problemy do rozwiązania oraz cele inicjatywy regulacyjnej. Diagnoza stanu powinna obejmować w szczególności badania komparatywne (Kwiek 2010) oraz benchmarking (Woźnicki, Morawski, Luterek i Degtyarova 2015) w szkolnictwie wyższym.

\section{Podsumowanie}

Postulowana deregulacja o charakterze selektywnym staje się nowym elementem koncepcji stanowienia prawa w szkolnictwie wyższym, ze wskazaniem niezbędnych obszarów regulacji. Istotna jest zasada autonomii uczelni jako wartości kluczowej 
w systemie szkolnictwa wyższego. Tworząc założenia do nowej ustawy, co stanowi niezwykle istotny i niezbędny etap w postępowaniu legislacyjnym, powinno się dążyć do usuwania nadregulacji w systemie szkolnictwa wyższego, w tym eliminować udział państwa w mikrozarządzaniu uczelnią, a także różnicować nakładane na uczelnie rygory ustawowe dotyczące dysponowania środkami finansowymi w zależności od źródła ich pochodzenia, umożliwiając tym samym racjonalizację ich działania.

Należy postrzegać problem deregulacji, mającej w szkolnictwie wyższym z założenia charakter selektywny, na szerszym tle uwarunkowań związanych ze stanowieniem prawa. Właściwej regulacji spełniającej wymogi deregulacyjne służy utrzymywanie standardów prawidłowej legislacji oraz stosowanie dobrych praktyk w tym zakresie (patrz Dodatek). Odwoływanie się w procesie interpretacji przepisów prawa do jego strony funkcjonalnej, a nie jedynie gramatycznej, która formalnie ma pierwszeństwo, ma w szkolnictwie wyższym wielkie znaczenie. Należy unikać promowania tzw. zasady tępego legalizmu.

Deregulacje nie powinny naruszać zasad autonomii i odpowiedzialności uczelni, które muszą być ze sobą ściśle powiązane. Im więcej autonomii, tym więcej odpowiedzialności uczelni. Minister musi dysponować realnymi instrumentami sprawowania nadzoru, sprecyzowanego co do zakresu i sposobu w sposób ściśle wynikający z ustawy. Przejrzystość działań ministra i transparentność uczelni są istotnymi wartościami w systemie szkolnictwa wyższego. Statut musi pozostawać znakiem autonomii uczelni - źródłem prawa i regulatorem obejmującym więcej niż dziś kluczowych kwestii. Prawnym efektem deregulacji powinien być wzrost znaczenia regulacji uczelnianej, dokonywanej przede wszystkim w ramach statutu, z uwzględnieniem zakresu nadzoru prawnego wykonywanego przez właściwego ministra lub w jego imieniu. Deregulację należy postrzegać również pod kątem kształtowania prawnych instrumentów w obszarze governance w szkolnictwie wyższym, określających ład systemowy i zasady sprawowania władztwa w szkołach wyższych.

Autor wyraża podziękowanie mgr Natalii Kraśniewskiej za pomoc przy opracowaniu artykułu.

\section{Dodatek \\ Znaczenie dobrych praktyk}

Warunkiem osiągnięcia sukcesu w postępowaniu deregulacyjnym jest spełnienie wymogów i reguł dobrych praktyk zawartych w Zielonej Księdze (2013):

Podnoszona w dyskusjach publicznych słabość systemu legislacyjnego w Polsce wynika głównie z braku fachowego zaplecza dla działań politycznych i ściśle legislacyjnych, 
z braku instytucjonalnego porządku w procesie stanowienia prawa oraz z niskiej jakości prawnej regulacji tego procesu [...]. Poprawę systemu stanowienia prawa można osiągnąć poprzez zwiększenie roli przygotowania oceny wpływu regulacji, udziału obywateli w procesie przygotowywania oceny wpływu, odpowiedzialności autora aktu prawnego za skutki jego wdrożenia [...]. Duże znaczenie należy przypisać dobrym zwyczajom, wykorzystywaniu najlepszych praktyk, wzorowaniu się na metodach wypracowanych w innych systemach [...]. Druga sfera działań naprawczych to obszar samoregulacyjny - z kodeksami dobrych praktyk, instrukcjami i wytycznymi. Tego typu dokumenty nie rodzą powinności prawnych, nie są źródłem praw i obowiązków, ale na autorów, zobowiązujących się do ich stosowania, nakładają poczucie odpowiedzialności za postępowanie zgodne z ich brzmieniem.

Istotne stwierdzenia z tym związane znajdują się też w stanowisku wspólnym Prezydium KRASP, Prezydium PAN oraz Prezydium RGNiSW z dnia 5 lipca 2013 r. 3:

Prezydium Konferencji Rektorów Akademickich Szkół Polskich, Prezydium Polskiej Akademii Nauk oraz Prezydium Rady Głównej Nauki i Szkolnictwa Wyższego przedstawiają wspólne stanowisko w sprawie zasad prowadzenia procesu legislacyjnego w odniesieniu do szkolnictwa wyższego i nauki.

Działanie systemu szkolnictwa wyższego i nauki wymaga wprowadzania nowych regulacji prawnych w sposób nadążający za obserwowanymi i prognozowanymi zmianami w jego otoczeniu. Działania legislacyjne powinny być prowadzone w sposób przewidywalny dla środowisk akademickich i naukowych, przy zapewnieniu regulacji stabilnych w dłuższym okresie, w szczególności dotyczących reguł finansowania i polityki kadrowej.

Wprowadzanie zmian w ustawach i rozporządzeniach powinno być poprzedzone nie tylko formalnym spełnieniem wymogów konsultacji społecznych, ale przede wszystkim realnym współdziałaniem zainteresowanych ministerstw z przedstawicielami ustawowo umocowanych, reprezentatywnych organów i organizacji działających na szczeblu centralnym w szkolnictwie wyższym i nauce.

Częste inicjowanie działań legislacyjnych prowadzonych pospiesznie i nierzadko przy braku zrozumienia i poparcia ze strony środowisk akademickich i naukowych, w warunkach braku dialogu w poszukiwaniu najlepszych rozwiązań, prowadzi do niejasności dotyczących stanu prawnego.

Za niewłaściwe należy uznawać wprowadzanie regulacji nadmiarowych, z przerostem wymogów administracyjnych i biurokratyzujących działalność instytucji i pracowników naukowych. Dotyczy to w szczególności nadmiaru i zbyt szczegółowego charakteru rozporządzeń wydawanych często z opóźnieniem naruszającym wymagane zasady techniki legislacyjnej.

Regulacje ustawowe nie mogą ingerować w statutowe reguły działania organów i organizacji reprezentatywnych w systemie szkolnictwa wyższego.

3 http://www.krasp.org.pl/pliki/982d2fddbff5290obo425a8f5ca289dd.pdf [12.08.2014]. 
Uznając przedstawione wartości za fundamentalne dla niezakłóconego rozwoju szkolnictwa wyższego i nauki, deklarujemy gotowość aktywnego uczestniczenia w pracach legislacyjnych.

\section{Literatura}

Degtyarova, I. (2016). Zarządzanie, governance i polityka publiczna w systemie szkolnictwa wyższego: Polska i Ukraina. Studia z Polityki Publicznej. 3(11): 159-172.

Izdebski, H. (red.) (2017). Ustawa 2.o. Założenia systemu szkolnictwa wyższego: Założenia do projektu ustawy. Kierownik projektu: prof. dr hab. Hubert Izdebski, opracowane przez zespól. Warszawa.

Kwiek, M. (2010). Transformacje uniwersytetu. Zmiany instytucjonalne i ewolucje polityki edukacyjnej w Europie. Poznań: Wyd. Naukowe UAM.

Kwiek, M. (2015). The unfading power of collegiality? University governance in Poland in a European comparative and quantitative perspective. International Journal of Educational Development. 43: 77-89.

Kwiek, M. i in. (2016). Projekt założeń do ustawy Prawo o szkolnictwie wyższym. Poznań: Uniwersytet im. A. Mickiewicza.

Program rozwoju szkolnictwa wyższego do 2020 r. Część I-V (2015). Warszawa: FRP-KRASP.

Radwan, A. (red.) (2017). Plus ratio quam vis consuetudinis. Reforma nauki i akademii $w$ Ustawie 2.o. Wyd. 2. Kraków: Oficyna Allerhanda.

Rozporządzenie Prezesa Rady Ministrów z dnia 20 czerwca 2002 r. w sprawie „Zasad techniki prawodawczej”, Dz.U. nr 100, poz. 908.

Strategia rozwoju szkolnictwa wyższego 2010-2020. Projekt środowiskowy (2009). Warszawa: FRP-KRASP.

Ustawa z dnia 27 lipca 2005 r. Prawo o szkolnictwie wyższym, Dz.U. nr 164, poz. 1365.

Woźnicki J. (2007). Uczelnie akademickie jako instytucje życia publicznego. Warszawa: Fundacja Rektorów Polskich.

Woźnicki, J. (2010). Prezentacja Strategy for development of higher education system in 2010-2020. Proposal of Polish Academic Community, wygłoszona podczas konferencji OECD/IMHE Higher Education in a World Changed Utterly: Doing More with Less. Paryż, 13-15 września 2010 r.

Woźnicki, J. (red.) (2015). Program rozwoju szkolnictwa wyższego do 2020 r. Deregulacja w systemie szkolnictwa wyższego. Warszawa: FRP-KRASP.

Woźnicki, J. (red.) (2017a). Raport nr 1 Komisji ds. Strategicznych Problemów Szkolnictwa Wyższego. Wstępne analizy, komentarze, propozycje i opinie do Ustawy 2.o. Warszawa.

Woźnicki, J. (red.) (2017b). Raport nr 2.1 Komisji ds. Strategicznych Problemów Szkolnictwa Wyższego. Wstępne propozycje do ustawy 2.o. Ustrój uczelni. Warszawa.

Woźnicki, J., Wyzwania i dylematy regulacyjne. Materiały niepublikowane.

Woźnicki, J., Degtyarova, I., Pacuska, M. (2015). Regulatory requirements towards HES reforms: The Polish case, Central European Higher Education Cooperation Conference Proceedings, Corvinus University of Budapest, Center for International Higher Education Studies and Central European University. 
Woźnicki, J., Morawski, R., Luterek, M., Degtyarova, I. (2015). Benchmarking in higher education: Polish experience. International Journal of Innovation and Learning. 17(2): 147-161.

Zielona Księga. System stanowienia prawa w Polsce (2013). Warszawa: Kancelaria Prezydenta Rzeczypospolitej Polskiej, Biuletyn Forum Debaty Publicznej nr 30.

\section{The postulate of the selective deregulation in higher education}

ABSTRACT. This article is dedicated to the issues of deregulation in terms of the matters covered by the Act Law on Higher Education from 2005. After further amendments to the Act in 2011, 2014 and 2016 the postulate of deregulation in the system of higher education has been clearly formulated in the public debate. It is important to raise the question whether or not its boundaries need to be defined. And if so, what are their nature and on what grounds they should be identified. The author of this article aims at defining such boundaries. In the paper, these issues were analyzed considering the scope and nature of the desired constraints. We define specific areas that have be regulated by legal framework. This means that the implementation of the deregulation should be selective, excluding certain issues from its scope. The composition of the article is as follows. Once introduced into the issue, the author presents arguments for the need to preserve higher education as a regulated sphere. The postulate of deregulation and its determinants are then introduced, distinguishing grammatical, functional and executive deregulation. In this context, the postulate of deregulation of selective character is formulated. Following the recognition of the importance of the constitutional principle of university autonomy, the postulated relationship Law - University Statute with regard to regulatory competences is presented. In conclusion, the author points out that the proposed deregulation with certain constraints fit well into the desired developmental conditions of the legal framework in the area of governance in higher education. In the Appendix, the author cites fragments of documents highlighting the importance of good practices in the area of lawmaking in higher education and science.

KEYWORDS: higher education, selective deregulation, university autonomy, law, statute

CYTOWANIE: Woźnicki, J. (2017). Postulat selektywnego charakteru deregulacji w szkolnictwie wyższym. Nauka i Szkolnictwo Wyższe. 2(50): 91-105. DOI: 10.14746/nisw.2017.2.4.

JERZY WOŹNICKI - profesor zwyczajny Politechniki Warszawskiej, a w latach 1996-2002 jej rektor, przewodniczący Rady Głównej Nauki i Szkolnictwa Wyższego (od 2014 r.), prezes Fundacji Rektorów Polskich (od 2002 r.), dyrektor Instytutu Społeczeństwa Wiedzy (od 2003 r.), przewodniczący Konferencji Rektorów Akademickich Szkół Polskich (1999-2002), członek Prezydium KRASP i przewodniczący Komisji ds. Strategicznych Problemów Szkolnictwa Wyższego (od 2016 r.), członek Europejskiej Akademii Nauk i Sztuk, Sekcja V „Nauki Społeczne, Prawo i Ekonomia” (2015). W latach 2011-2012 członek Zespołu CK ds. nowych dyscyplin naukowych - wnioskodawca i ekspert odpowiedzialny za opis nowej dyscypliny pn. nauki o polityce publicznej. Przewodniczący Komitetu Sterującego wspólnego projektu KRASP-FRP pn. „Program rozwoju szkolnictwa wyższego do 2020 r.” (2013-2015). Członek Komitetu Etyki w Nauce przy Prezydium PAN. Jest pomysłodawcą i współautorem kodeksu Dobre praktyki w szkołach wyższych KRASP. E-mail: frpfund@mbox.pw.edu.pl. 